\title{
RELIGIOUS DEMOCRATIZATION IN INDONESIA: Strengthening the Procedural and Substantial Religious Democracy
}

\author{
Eka Hendry AR. \\ Center for Acceleration of Inter-Religious and Ethnic Understanding, \\ Pontianak
}

\begin{abstract}
Inspired by the book of Michael Mann about the dark side of democracy that discusses the paradox between the ideality of democratic values and empirical realities of violence in the name of freedom (democracy), this paper begins with the exposure of the paradox, such as the rise of the violent conflict between groups of people (both ethnic and religious-based) and the high prevalence of violence between religious groups in Indonesia. Even worse, a very wrenching violence involves state actors (rulers). This paper tries to understand the roots of the paradox, with a look at how the relationship between state and religion and the religious community trend of Indonesia (especially Muslims). The author argues that the democratization of religion is a solution to the issues. To answer what kind of religious democracy lives in Indonesia, the author analyzes through a religious procedural (or constitutional) democratic dimension and religious substantial democratic dimension. The phenomenon of disobedience of law and system and the euphoria of law-making that reflects "intolerance" in several places in Indonesia display the fundamental issue in the religious procedural democracy. Whereas in the context of religious substantial democracy, the prevailing trend of religion that serves as a political and economic vehicle and ignores religion as a substantial aspect of the behavior of the Indonesian society has resulted in the marginalization of religious position and function. Then, the infiltration of the model of political Islam has also led to alienation of the character of the Islamic society of Indonesia, from a democratic pattern to a revival (radical) one. In this light, the author needs to present a strategy to encourage religious democracy in Indonesia, structurally through formulating the ideal relation model between state and religion and culturally through a substantial pattern of religion embedded with the character of Indonesian religious communities as well as the need to revitalize the true Indonesian Islamic model which will be intrinsically familiar with the principles of democracy.
\end{abstract}

Key words: Democracy, religious procedural, substantial democracy, intolerance, law and system of disobedience. 


\section{INTRODUCTION}

This paper is inspired by Michael Mann's book, “The Dark Side of Democracy”. In the book, Mann discussed the dark side of euphoria of freedom in several countries in the world. Through this book Mann revealed the paradox behind the ideality of democracy. It appears that behind the strong desire for democratic societies, the phenomenon of violence in the name of freedom also tends to escalate. It shows something of a contradiction, as though democracy and violence are two sides of the coin. It is a paradox because ideally democracy aims to contain violence (Susan, 2012: 160). Not lingering to argue about this issue, the author believes that, violence is definitely not part of the intrinsic principles of democracy. According to the author, violence is clearly a "dark passenger" in the ideal of democracy, and may serve as logical consequences of the collateral sacrifice that occurs during the maturity in democracy. This important assertion is necessary to be stated earlier in this paper as we do not want to get trapped into the mistaken assumption that democracy leads to a new outbreak of conflict everywhere. Should this be the case, then this is a step backward.

The same thing also became Mann's concern (2005: 2); he argued that democracy should remain an ideal, not something synonymous with violence. It coincided with the growing likelihood of a violent practice of democracy. Therefore, we need to straighten it out that the democracy 'show' must go on, after that we will deal with this tangle in which deviations might occur.

"My first thesis concerns the broad historical era in which murderous cleansing became common. Murderous cleansing in modern, because it is the dark side of democracy. Let me make clear at the outset that I do not claim that democracies routinely commit murderous cleansing. Very few have done so. Nor do I reject democracy as an ideal -I endorse that ideal. Yet democracy has always carried with it the possibility that the majority might tyrannize minorities, and this possibility carries more ominous consequences in certain types of multiethnic environments"(Mann, 2005:2).

The author's mindset is clear that violence is not part of the order of the ideal of democracy; it is a form of distortion of democracy. In other words, while the violence that arises along with democratization, it is regarded as a form of deviation in the internalization of the values of democracy. So there is no reason to get rid of the democracy of a nation's life.

To prove what is stated by Michael Mann, we can look at countries that were 
on the path to democracy always had violent conflicts in the form of ethnic cleansing and genocide; examples can be seen in Bosnia and Herzegovina (1999), Angola, Armenia, Azerbaijan, Georgia, India, Burma, Sri Lanka, Sudan, Bangladesh, Belgium, Burundi, Bhutan, Ethiopia, Iraq, Latvia, Mali, Moldova, Nigeria, Northern Ireland, Spain, Turkey and the Philippines, including in Indonesia. (El Fatih A. Abdel Salam, 2008). Indonesia, in the wake of the reform movement as a starting point toward a democratic society, was also overshadowed by violent conflicts. Just to mention a few among them are conflicts that took place Ambon, Poso, Sambas and Sampit. The violent conflicts involved ethnic groups and religious. These conflicts have continued to this day with the motif that continues to grow, such as those related to the elections of regional heads, and the natural resource issues. The conflict that occurred during the plan for the establishment of North Tapanuli Province resulted in the death of the Chairman of the local parliament. The violence also occurred between local people and a company in Lampung, and between the authorities and the people of Musi Rawas in South Sumatera due to the desire for the creation of a new district. Violent acts in the name of religion also became a trend in the political context. In the last three years, the acts of violence between religious groups also increased. Refusal accompanied by acts of violence against religious groups considered "heretical" has also become widespread i.e. in the case of Ahmadiyah group in Ceukesik, Temanggung and Mataram. Forced closure of houses of worship, bomb threats against parties deemed "liberal" minded, burning of the Shi'ah Islamic boarding school were just among a few to mention.

The above events of conflicts are part of the journey toward the maturity of democracy in several countries in the world, including Indonesia. According to Donald L Horowitz (in Larry Diamond and Marc F. Plattner 1998: 43) the conflicts on the path to democracy in many countries in Africa, Asia and Eastern Europe tend to be the cause of the failure of democratization. This paper will not discuss these conflicts as there have been many writers who examined the issue. It focuses on the implications of the violent conflicts on the future religious democracy in relation to the state and between religious believers in Indonesia. The author's thesis is that religious democracy is the answer to all forms of deviation of the freedom of expression (democracy). This paper is presented firstly to discuss the root issues that arise in the paradox between the ideality of democracy that is considered appropriate for Indonesia and the empirical realities of life found in the nature of democracy. Secondly, it intends to question the model inter-relations that fit between state and religion in Indonesia. This question arises because the state also became part of the intolerance actor. Thirdly, this paper also aims to find out 
the strategies to encourage the realization of democratization of religion in Indonesia.

\section{INTERPRETING DEMOCRACY IN THE CONTEXT OF INDONESIA}

Democracy is in fact a constructive instrument if implemented correctly. However it could also be the opposite when democracy is a mere jargon. Michael Mann explicitly explained that many people have mistakenly interpreted democracy and this has eventually resulted in counterproductive acts in the name of democracy. Therefore, there are a lot of criticisms (or warning) against it. Thomas Hobbes (in Runciman, 2012: 7) argued that democracy is no more than just a stage for hypocritical politicians. In the name of democracy, evil politicians are feeding lies on the community. M Natsir criticized the guided democracy under Sukarno in which Natsir said that in the guided democracy era everything was there, except the democracy itself (Hendry, 2013: 4). This is a form of satire that democracy only exists as mere jargon. Natsir warned that democracy should not become party-cracy or crony-cracy (An-Na'im, 2007: 441). Therefore democracy should be practiced according to its main purpose.

Democracy is in fact a humanitarian ideal and the life of the nation. It is meant to uplift the human sovereignty, the sovereignty of the law in the context of the life of nation and the state. For that purpose, then democracy must be manifested into every aspect of human life, both in the context of personal and collective scope. It must serve as the basis for human thought and behavior because the substance of democracy is "freedom", the freedom of thought, freedom of speech and the right to equality, equal rights before the law, and the right to a decent life (socially and economically). Therefore, these democratic values should be allowed to grow in a range of institution of life, such as in the academic, economic and social, as well as in cultural and religious institutions.

In the context of democratic practice, the term is usually divided into two categories namely the formal (or procedural) category and the substantial category. This formal category is associated with democratization mechanism as stipulated in the Constitution, while the substantial category should be reflected in the way one thinks, behaves and acts when implementing democracy. The latter often refers to the democratic culture. For example when we are grouping democracy with political analysis unit, it is usually divided into two categories, namely procedural or constitutional democracy and substantial democracy. Procedural democracy is a condition in which the will of the freedom of speech and political aspirations is channeled through formal 
political procedure regulated in accordance with the Constitution, such as the process of the elections. Procedural democracy highlights how sovereignty is in the hands of the people and the Constitution, while substantial democracy is how democratic values such as freedom to convey the aspirations, the readiness of accepting and appreciating differences, and open attitude to conduct deliberations. In reality, especially in cases such as the election of the head of a region, procedural democracy looks relatively good, while in the substantial context it still has a lot of serious issues.

Then what about in the context of religious life? Formal or procedural democracy manifests itself in the form of statutory rules that govern the relations between religious groups, while in its substantial category it should be interpreted into a way of thinking, attitudes and social behavior, such as practicing religious tolerance, respecting different beliefs, providing a room for the growing development of doctrines different from the mainstream religions, as well as the ability to work together in diversity. In the context of politics, democracy in the procedural category relatively runs better than substantial democracy, but in the context of the democratization of religion, both in this category still have crucial issues. As a country that upholds the values of religion, though not a theocracy, Indonesia still has some crucial issues related to the question of the relations between religious groups and between state and religious institutions.

Formally, the state is concerned with regulating the relations between religious groups by issuing a variety of laws such as freedom of religion as stated explicitly in the Constitution article 29 paragraph 1,2 and 3. In addition, the state also regulates on how the spread of religion and the construction worship houses should be done, how disputes between religious groups should be resolved as in the issuance of the Joint Decree of the Minister Religious Affairs and the Minister of Interior No. 8 and 9/ 2006 on the guidelines for Heads of the Regions to maintain religious harmony as a replacement for the Joint Decree number $1 / 1969$.

The problem, according to Mohammad Fathuddin (in Hendry et al., 2012: 41 ) is that, in practice there are still a lot of controversies mainly related to the substance of the law contained in the decree. Fathuddin noted there are at least five problems arising from the joint decree, namely first, the administrative requirements for the construction of houses of worship must be accompanied by a recommendation from the FKUB (Inter-Religious Harmony Forum), and it more difficult to obtain compared to joint decree (which only requires the permission of the Department of Religious Affairs and Chairman of the RT/RW); second, despite being formed by the people, FKUB is more 
bureaucratic and structural in nature. FKUB is considered to be the puppet of local governments. There have been concerns that It is concerned that FKUB may serve as political tools to suppress the people; third, the bureaucracy for getting permit to construct places of worship may trigger minority and majority sentiments between religious followers; fourth, the minority and majority politics may likely cause segregation in society based on religion; fifth, a difficult bureaucracy regarding the construction of houses of worship is potential to cause suspicion among the minority.

A study conducted by the author together with Hamzien Bunsu and Ria Hayatunnur Taqwa (2012) in relation to the enactment of the PBM (joint decree) showed that despite the PBM No. 8 and 9 is already far better than that of No. $1 / 1969$, it turns out that the PBM is still problematic. It is even considered to be a trigger of dispute in the society, as viewed by some to contain discrimination against minority groups. This research showed that religious groups such as Christians (formerly Protestants) usually build a Church based on ethnic groups, for example the Church of Batak, Dayak etc. They are usually a minority ethnic group in a certain region and are in need of a house of worship. The construction is sometimes hampered by administrative provisions from the $\mathrm{PBM}$ that requires a certain number of people belonging to the ethnic group. The PBM is in fact a trigger issue, and is considered the root of discrimination against minority groups.

In terms of the substance of democracy, it seems that a lot of data to date that show that, the democratization of religion remains a crucial issue for Indonesia. It can be seen in table 1 and 2, where the number of cases of intolerance is still quite high.

Table 1

183 Non-state actors' forms of action

\begin{tabular}{|l|l|}
\hline Form of action & Number of cases \\
\hline Condoning & 12 \\
\hline Intimidation & 4 \\
\hline Intolerance & 52 \\
\hline Report to the authority & 3 \\
\hline Prohibition of religious activities & 6 \\
\hline Prohibition of religious sects & 3 \\
\hline Prohibition of religious observance & 16 \\
\hline Prohibition of construction of worship houses & 17 \\
\hline Coercion of faith & 2 \\
\hline Arson of property & 1 \\
\hline Arson of worship houses & 5 \\
\hline
\end{tabular}




\begin{tabular}{|l|l|}
\hline Road blockage & 1 \\
\hline Property teardown & 1 \\
\hline Dispersion of religious activities & 1 \\
\hline Physical harassment & 1 \\
\hline Property destruction & 7 \\
\hline Destruction of places of worship & 21 \\
\hline Sealing off places of worship & 8 \\
\hline Closure of places of worship & 1 \\
\hline Expulsion & 1 \\
\hline Assault & 8 \\
\hline Perversion of religious teachings & 11 \\
\hline Attempted assault & 1 \\
\hline Total & 183 \\
\hline
\end{tabular}

Source : (Ismail Hasani and Bonar Tigor N. [ed], 2010:23-24)

Based on reports from the Setara Institute in 2010 there were 216 violations of religious events with 286 forms of action occurring in 20 provinces throughout Indonesia. (Hasani and Tigor N. (ed.), 2010: 19) The data in 2011 as presented in the annual report of the religious life in Indonesia issued by the CRCS UGM showed that there were 7 cases of alleged desecration of religion (excluding the case of Ahmadiyah) including accusations of heresy against Abraham Millah Community in Aceh and Medan, the expulsion of the Shi'ah community in Sampang Madura. In the case of Ahmadiyah, CRCS reported violent acts against 20 communities throughout January - August 2011. The forms of violence actions like raids and destruction of homes, demolition of mosques, burning the books, beating, assault, murder and the dismantling of the tombs of the adherents of the Ahmadiyah (Center for Religious and Cross-Cultural Studies, 2012).

The reports compiled by the Setara Institute (in 2012) showed there have been 264 events of violation of freedom of religion with 371 violent acts in 28 provinces. There were five provinces with the highest levels of offence namely West Java (76) events, East Java (42), Aceh (36), Central Java (30), and South Sulawesi (17) (Setara Institute, 2012) Of the 371 cases of violation of religious freedom, 145 (39\%) of them were actions involving the state authority. Of the 145 cases, 117 were actions taken by the state and 28 were cases of negligence by the state (Setara Institute 2011:5) For comparison, the same data was also reported by The Wahid Institute. During 2011 (January-December), there were 110 cases of violations of freedom of religion. When compared to the year 2011, the violation of freedom of religion that occurred in 2012 reached 
110 cases as compared to 93 cases or approximately $8 \%$ increase. The monthly average of violation cases in 2011 was 7, while in 2012 it increased to an average of 9 cases per month. Even if the cases December were not counted, the average violation was 10 cases per month. The Wahid Institute concluded that the protection of and respect for religious freedom is getting worse. There has been an increase in the cases of violations of freedom of religion in the last three years. (The Wahid Institute, 2012: 3-4). The same thing was reported by the Setara Intitute that negligence by the state apparatuses still occupied the highest cases (33 cases) as seen in graph 1.

The above data shows the forms of violation of freedom of religion committed by vigilantes (in addition to violations by the state institutions). Of the various forms of action, the dominant offense was an attitude of intolerance (52 cases) and the destruction of houses of worship (21 cases). As for the religious groups who are likely to become victim are the Jemaat Kristiani (Christian congregants) (75 cases) and the Ahmadiyah (50 cases). The places of worship that received attacks include the Church of Jemaat Kristiani (43), Ahmadiyah Mosque (9) and several Islamic Ummah Mosques. (Hasani and Tigor N. [ed.], 2010: 26-27)

The data (tables 1 and 2) show that, the democratization of religion in Indonesia (both procedural and substantial) remains a serious problem. What factors may cause this to happen. To answer the question, the author conducted an analysis in two dimensions, first, related to the democratization of religion in the procedural dimension and second, related to religious democracy in the substantial dimension.

Table 2

Violation of religious freedom in 2012 (The Wahid Institute's version)

\begin{tabular}{|l|l|}
\hline Form of violation & Number of cases \\
\hline Negligence by the state apparatus & 33 \\
\hline Worship house ban & 26 \\
\hline Religious activity ban & 18 \\
\hline Criminalization of Faith & 17 \\
\hline Coercion of faith & 12 \\
\hline Intimidation & 4 \\
\hline
\end{tabular}

\section{PROBLEMS OF (PROCEDURAL) RELIGIOUS DEMOCRACY}

The procedural religious democratization with regard to factors that lead to the implementation of religious democracy in Indonesia is still problematic. 
Among the factors are the existence of bias from the model power relations between state and religion (state and religious followers). Then, the domino effect of the matter is the legitimacy of the state in enforcing the rules that govern the relationship between religious followers.

\section{a. Bias from the interests of the stability of power}

The relation model is not too firm between the sate and religions in Indonesia, creating a dilemma for Indonesian government. According to Abdullahi Ahmed An-Na'im (2007: 401) the government is faced with the dilemma whether the state should impose the implementation of Shariah, for example, by using the 'hands' of power, or the state should be neutral and merely in charge of safeguarding the rights of citizens to observe their faith. In the context of religious doctrine, does the state have to choose between taking the role of legalizing a religious pragmatism and letting the religious followers with their own dialectics.

In fact, the state has always intervened in the religious affairs by serving as a 'judge' regarding religious doctrines. It is justified due to the potential instability effects certain religious teachings may have on the community. In such condition, the state usually loses its objectivity and impartiality because of the strong pressure from the majority group. As in the case of Ahmadiyah where it was declared heretical by MUI decades ago, but only in the last few years has there been a strong pressure on the government to "eradicate" it. So it is natural that the country is considered to be part of this intolerance. If we adopt a purely secular state, the state can freely stay away from the matter; or in a theocratic state, intervention in any religious decisions can be done earlier. In our case, the state tends to keep social stability as the logic of power and justification to get into the realm of religion.

The tendency of the state policy on religion in the context of relation model in Indonesia will bear the following impact: first, the state will explicitly act on the tendency of the majority's interests, as a pretext for maintaining stability because of the risk of dealing with the minority groups is smaller than the majority. Second, religious groups that have access to those in power will have the privilege of being the party that determines the direction of the state policy in religious affairs. In the context of Indonesia, the organizations such as the Nahdhatul Ulama have access to the center of power so they are more dominant, for example the decision of the start of Ramadan and Eid.

Consequently, Indonesia's religious groups will be split into multiple polarization based on interests and ideology based on their religious beliefs. Therefore 'the face of religion' would also be split into structural and cultural 
restrictions. Religious institutions whose legitimacy is recognized by the state and is regarded as the representation of various religious institutions in Indonesia such as the MUI will conform to the representation of the government's efforts in structuring religion. (Alkaf, 2011:211) In other words, the potential for using religious institutions to 'extend the hand' power will be even greater even though the MUI itself would not admit to be an extension of the authority.

\section{b. Weak law enforcement (due to law and system disobedience)}

Based on research conducted by the author in collaboration with Hamzien Bunsu and Ria Hayatunnurtaqwa (2012), among the root causes of religious dispute is a question of law disobedience. According to Benget Silitongga (in Hendry et al., 2012: 39) there are two patterns of law disobedience; acting against the legal decisions and ignoring the political decisions. Benget cited the cases of dispute in the construction of HKBP Philadelphia church in Jakarta and GKI Yasmin in Bogor. The Supreme Court's decision was to permit the construction of houses of worship, but at the local level, the decision of the Court was not implemented by Local Authorities for various reasons. Related to the disregard of political decision, Benget took the case of the sealing of a number of worship houses in Aceh Singkil. The Joint Decree No. 9 and 8/2006 turned out to be ignored by local political decisions i.e. the agreement of the ulemas and the community leaders. The root of the problems is because the law does not run properly; I other words, the law has lost to the pressure from the political forces and the masses in the region. The study concluded that Benget's argument was correct with regard to all the administrative procedures according to applicable regulations. However, in the case the writer pointed out above (in the previous chapter) the manipulation of legislation is of course different. It is important to find out the cause why they choose to manipulate rather than have a dialog or find an open approach to the issue.

To answer this question, researchers saw the criticisms of the Joint Decree No. 9 and 8/2006 as a relevant subject to discuss. From the beginning there were parties that argued that the Joint Decree is discriminatory and reflect a misleading logic. The Decree is discriminatory because it hurts the minority groups while they also need places of worship protected by the 1945 Constitution. It is misleading at least for two reasons namely: first, the local-based proven procedures are often problematic as the dynamics and local interests that are filled with ethnic/religious sentiment in the context of vulnerable local politics on religious issues such as the construction of houses of worship. Second, houses of worship are not the same with other secular buildings, so the permit should not be the same because houses of worship are 
intended to glorify God and should be protected by the state (Silitonga, 2012). According to John Cameron (in Susan, 2012: 165) behavior of neglect in the legal system (disobedience to system) typically occurs for two reasons: first, it is associated with euphoria of the excessive freedom of interpretation. Second, it deals with confidence in the agencies that have the authority in law enforcement or the system itself. To explain latter, James Manor (in Susan, 2012: 166) asserted in the case of countries that recently began the process of democracy, public distrust of government authority system is due to irregularities within the government such as corruption, sluggish public services and the practice of clientelism.

So, why does the legislation fail to produce effective measures especially in the case of religious dispute? This may be due to two factors, namely the existence of the majority group euphoria that has "power" to impose their views and interests on the minority and the government. The government is also 'powerless' when dealing with the pressure from the majority. The birth of 'Shariah' related regional regulation in several parts of Indonesia may represent this assumption. For instance, the East Java Governor Regulation No. 55/2012 on conducting religious activities and monitoring of heresy in East Java. Then, on April 4, 2012 there was a discussion on a draft law regarding the improvement of quality early Islamic education in Tasikmalaya District. The Local Government of Tasikmalaya also issued Regulation No. 12/2009 on issues related to Islamic Values. It contains values in a community life based on teachings of the Islamic religion in Tasikmalaya, West Java. Similarly, the Joint Decree No. 21/2005 contained a ban on Ahmadiyah's activities in Cianjur. (The Wahid Institute, 2012; Mudzakkir, 2011: 13-14). A lack of trust in the government due to its inconsistency regarding the process of law enforcement may also contribute to issues faced by the minority. The law is still regarded as being discriminatory and has yet to provide relevant implications in addressing the existing problems. Corruption cases from time to time are becoming even more rampant. As a result, an expression of "protest" from society is the disobedience law issued by the government.

\section{PROBLEMS OF (SUBSTANTIAL) RELIGIOUS DEMOCRACY}

The democratization of religion on the substantial level is closely associated with the root cause of our difficulties in developing a way of thinking, behaving and acting democratically in terms of religious affairs. 


\section{a. Transforming the Institutionalization of Religion into Religious Sub- stantialization}

As far as violence involving religious followers (especially in Indonesia) is concern, religion has always been described as the 'victim' by the other more empirical factors, such as political expediency and the seizure of economic resources. Religion has been 'utilized' merely as a campaign tool and the symbols for political or economic purposes. We can easily hear the average political candidate 'selling' the issues of religion as a way to gain sympathy from voters (gimmick politics). Even in the fields of economy, economic institutions ranging from banks, supermarkets, service and property businesses are also using 'religious terms' as the icon (in the form of Shariah or Islamic products).

There is gap between the symbols or the institutionalization of religion and the substantial awareness of religion itself. In other words, pragmatic interests have become a more dominant motive than the religious orientation. As a matter of fact, in the context of Indonesian society, religion is vital, serving as a worldview, ideological base (social and political), norm and the living standards of the society. Religion inspires a spirit of unity as the Islamic Union. Religion is also a motor, a process of transformation in society, and even an initiator spirit of liberation and resistance (Liberation theology), such as the resistance against the invaders. It lives and is really functional for the community of Indonesia. In fact, religion is intertwined with various dimensions of human life.

Without question, when religion loses its substantial dimensions, it is 'castrated' or dwarfed of its position and function in society. Religion is not viewed as something important; it is seen as merely a complement to understand the society. In science, analysts and researchers consider religion merely a minor analysis unit. It is seen as a mechanical positive instrument, helpless without energy from other areas. Therefore, when there is violence involving religion, almost all experts say that the root of the problem is politics and economy because religion is just a symbolic aspect.

Yet when we are talking about historical religion, religious life flourished in one objective space i.e. Indonesia. The country is very divergent in terms of ethnicity, race, religion, culture and customs. The country resembles a mosaic. The history of this nation can hardly be separated from religion, from animism, Hinduism, Hindu-Buddhism, Islam and Christianity. Religion is transferred to the basic Constitution of the country, forming the basis of the country although it is neither explicit nor formal. Later in the context of cultural values of the community, these values are derived from the beliefs of Buddhism Hinduism, Islam and Christianity. Therefore, almost all aspects of 
people's lives in this country are somehow related to religious values (beliefs, rituals and religious moral values). An embedded term might be correct here to illustrate a reciprocal relationship between religious values and other institutions. So, there should be efforts to straighten out the understanding that religion, in addition to the symbolic aspect of religious life, serves as a substantial awareness. As a substantial awareness, religious values form the awareness, attitude and behavior as well as the virtue values such as truth, justice and humanity.

When the religion of seen as a substantial awareness, further implications (in the scientific context), religion will be one of the major analysis unit that stands equal to other major political, economic and social units. Therefore it is important that anyone who wants to understand the phenomenon of radicalization in the Indonesian society should also understand its tendency of (formal and substantial) religious models. It is an uncontested logic of the public that political and economic factors serve as the root of social problems. However, it is less comprehensive to understand the phenomenon of radicalism in Indonesia only from the two factors mentioned without placing a religious analysis as one of the major analysis units because it is the fact that happening in the Indonesian society.

\section{b. Religious Models Developed in Indonesia (alienation from the culture of Indonesian society)}

The religious model that developed in Indonesia is the result of acculturation among religious traditions unique to Indonesia and the Middle East. In some ways, the mosaic of cultures and customs of the Indonesian society really stand out, as seen in the various forms 'religious tradition of technology' in Indonesia such as tahlilan, religious arts, celebration, etc. But in the last decade, the religious trend of the Middle Eastern-style seems quite noticeable.

"The diversity of religious practices in Indonesia is difficult for a
limited space to sum up. I would only emphasize that the tradition
of tolerance which develops among the various different religious
practices that seem to be eroded by a different hegemonic reli-
gious discourse in recent times" (An-Na'im, 2007: 409).

It is seen in terms of the discourse developed, then of religious symbols worn, then the approaches in implementing Islam in Indonesia. The discourse about the enforcement of Islamic Shariah as the ideological alternative is so fast. As the State has not yet implemented, the Shariah related legislation can be found in the form of local government policies such as Shariah Regional Regulations. Symbols are used to highlight the relative model of the Middle East such as 
clothing, banners, flags, etc. Similarly, the approaches in fighting for Islam appear to be aggressive (such as the cases of terrorism). Such model actually had no precedence in the history of the development of Islam, because from the beginning we know that the process of the arrival of Islam in Indonesia was very "smooth" and peaceful. Acculturation between Islam and Indonesian cultures that were previously influenced by the Hindu teachings could run well. Therefore, decades after the country became independent, we can see the peaceful way of practicing religion among Muslims.

The original character of the Indonesian culture was noticeable in the conduct of religious Muslims, so countries such as the United States and those in Europe prefer to make the Indonesian humanist Muslims model as a prototype of contemporary Muslims to be promoted to the outside world as a counter image of the hegemony of the Middle Eastern-style Islamic prototypes that are considered tough, less humanist and against modernity. Today, that hope is fading away as a result of the increasingly intolerant, reactive and exclusive face of religion. This is also due to the deviation religion from in Indonesia. In Abdurrahman Wahid's term, Indonesian Islam has gone through the process of nativism, or Islam that has intertwined with the culture and behavior of the Indonesian society. This wave may be due to the strong currents of political Islamic dominance, rather than cultural Islam.

The urge to present Islam with Indonesian mosaic is because Indonesian Islam that has been growing substantially in dimensions of democracy. Islam itself is substantially and historically proven to conform with democracy. From the beginning, Islam has introduced the principles of Deliberation (al-syura), equality (al-musawa), Justice (al-adalah), freedom (al-hurriyyah), trust (alamanah), peace (al-salam) and tolerance (al-tasamuh), all of which are the principles of democracy. (Abdul Salam Arif, 2004: 11-18). Furthermore, in the context of Indonesia, we can find a variety of customs and traditions which contain principles of democracy, such as the cultural pattern of the people of Aceh, Minangkabau, Batak, Malacca and Java Nazaruddin Sjamsuddin, (1996: 41; Mohammad Najib et al., 1996: 1437). By showing the pattern of Indonesian cultural Islam, we can expect to be able to present a more humanist and democratic religious model, not that of the exclusive, radical and antidemocracy.

\section{STRATEGIES TO EMBODY RELIGIOUS DEMOCRACY IN INDONESIA.}

It takes the right strategies to encourage the democratization of religion in Indonesia, both procedurally and substantially. The key to the embodiment 
of procedural religious democracy is a need of constitutional consensus about the relationship between the state and religion. What kind of relation model fits for a country like Indonesia, semi-secular model (to avoid secularism), semi-theocratic model (to avoid the authoritarian theocracy?); or should we maintain the current ambiguous model? A semi-secular model allows the state to accommodate and protect religions but it is not involved in any religious decisions, such as one on religious holy days, whether or not a particular religion is a heresy, halal food products, etc. Religious institutions, instead, make the decisions without the state's intervention. The state can intervene only when certain religious groups conduct unlawful acts (crime). A semitheocratic model is a model in which the state not only accommodates and protects religion, but it is also in control of any decision related to religious affairs. A theocratic state needs religion as the basis of the law, while in a semitheocratic state it does not, but the state has the right to intervene in religious decisions.

Although each model its strengths and weaknesses respectively, the author thinks that a semi-secular model perhaps is better suited for Indonesia if we want to encourage the procedural and substantial democratization of religion for the following reasons. First, procedurally the state will not be stuck into partiality in resolving religious issues. Second, it will foster maturity among religious followers in solving problems related to religious issues. The trend of inter-subjective thought and consciousness will be dominant when religious groups solve the problem with their own dialectics. Disobedience of the law will occur when decisions made by the state are deemed not in line with certain groups' interests. Third, the substance of the spirit of pluralism and multiculturalism is not simply an awareness of the diversity, but a way to manage diversity through dialog, mutual understanding, cohesion and cooperation in dealing with such differences. These are the core values of the substantial democratization of religion.

Therefore, we need to encourage the idea of (substantial) democracy as a basis for decision making when dealing with religious problems, not merely as a complementary tool which is peripheral in nature. Religion should become one of the macro-analysis units, which runs hand in hand with other social, political and economic components so we can really understand religious dimensions of the Indonesian society since the process of integration between religion and public life is running well so far. Thus, when we put a religious analysis unit aside, it means we become less comprehensive in our analysis. Last but not least, in the framework of the revitalization of the democratization of religion, it needs to revive the Indonesian religious image which presents 
the Islamic cultural face. The face of cultural Islam is intertwined with the cultural characteristics of the pluralist communities of Indonesia. It is the antithesis model of the Middle Eastrn Islam which is historically and culturally different from the actual history and culture of Indonesia. History proves that Indonesian Islam has its own mosaic, different from the models found in other countries. Being egalitarian, inclusive, peaceful and cosmopolitan is the nature of Indonesian Islamic culture which has been practiced for centuries and completely different from the character of the Middle Eastern Islam due to dissimilar experience, history and geographical conditions.

\section{BIBLIOGRAPHY}

An-Na'im, Abdullahi Ahmed. 2007. Islam dan Negara Sekuler : Menegosiasikan Masa Depan Syariah). Mizan. Bandung.

Arif, Abd. Salam. 2004. Politik Islam antara Aqidah dan Kekuasaan Negara (dalam A. Maftuh Abegebriel dkk.). 2004. Negara Tuhan : The Thematic Encyclopedia. SR-Ins Publishing. Yogyakarta.

Alkaf, Halid. 2011. Quo Vadis Liberalisme Islam Indonesia. Kompas. Jakarta. Effendi, Tadjuddin Noer. 1996. Demokrasi dalam Persfektif Budaya Batak. Dalam Mohammed Najib dkk. 1996. Demokrasi Dalam Persfektif Budaya Nusantara. LKPSM. Yogyakarta.

Hasani, Ismail dan Bonar Tigor Naipospos (ed). 2011. Negara Menyangkat, Kondisi Kebebasan Beragama/Berkeyakinan di Indonesia 2010. Pustaka Masyarakat Setara. Jakarta.

2011. Mengatur Kehidupan Beragama; Menjamin Kebebasan ? (Urgensi Kebutuhan RUU Jaminan Kebebasan Beragama/Berkeyakinan). Pustaka Masyarakat Setara. Jakarta.

Horowitz, Donald L., Demokrasi Pada Masyarakat Majemuk. Dalam: Larry Diamond dan Marc F. Plattner (ed), 1998, Nasionalisme, Konflik Etnik, dan Demokrasi (Terjemahan), Penerbit ITB, Bandung.

Hendry Ar, Eka. 2009. Sosiologi Konflik. STAIN Press didukung oleh Caireu STAIN Pontianak, WMC Semarang dan NUFFIC Belanda. Pontianak. Hendry Ar, Eka (at all). 2013. Peran Forum Kerukunan Ummat Beragama (FKUB) Dalam Penyelesaian Sengketa Pendirian Rumah Ibadah (Studi Terhadap FKUB Kota Pontianak). Laporan Penelitian Kompetitif STAIN Pontianak Tahun 2012. (Tidak diterbitkan). STAIN Pontianak.

Mann, Michael. 2005. The Dark Side of Democracy (Explaining Ethnic Cleansing). Cambridge University Press. Los Angeles (USA).

Mudzakir, Amin. Minoritasisasi Ahamdiyah di Indonesia. 2001. Jurnal Mas- 
yarakat Indonesia Majalah Ilmu-Ilmu Sosial Indonesia. Edisi xxxvii. No. 2. 2011. LIPI. Jakarta.

Nasution, Adnan Buyung. 2011. Demokrasi Konstitusional. Kompas Gramedia. Jakarta.

Runciman, David. 2012. Politik Muka Dua : Topeng Kekuasaan Dari Hobbes hingga Orwell. Pustaka Pelajar. Yogyakarta.

Susan, Novri. 2012. Negara Gagal Mengelola Konflik: Demokrasi dan Tata Kelola Konflik di Indonesia. Kopi dan Pustaka Pelajar. Yogyakarta.

The Wahid Institute. 2012. Ringkasan Eksekutif Laporan Akhir Tahun Kebebasan Beragama dan Intoleransi.

The Setara Institute. 2012. Presiden Tanpa Prakarsa (Kondisi Kebebasan Beragama/Berkeyakinan di Indonesia, 17 Desember 2012)

\section{Internet}

Abdel Salam, El Fatih A.,. Kerangka Teoritis Penyelesaian Konflik. Diakses dari: http://www.scripps.ohiou.edu (selasa, 21 okt 2008).

Hutomo, Nandro. 2010. Demokrasi Prosedural dalam Polemik Keistimewaan DIY 2010. http://iesdepedia.com/blog/2013/01/15/demokrasi-prosedural-teori-2/. (Selasa, 15 Mei 2013 
